\title{
СТИЛІСТИЧНІ ФУНКЦЇ̈ ЗВУКОПИСУ В ПОЕТИЧНОМУ МОВЛЕННІ УКРАЇНСЬКИХ ПОЕТІВ ПОЧАТКУ ХХ СТ.
}

Кабиш М. Ю. Стилістичні функції звукопису в поетичному мовленні українських поетів початку ХХ ст.

У статті визначено, розглянуто i проаналізовано стилістичні функції звукопису в індивідуальному стилі видатних поетів початку XX ст. На основі ілюстративного матеріалу показана роль звуконаслідування, як одного із прийомів звукопису.

Ключові слова: звукопис, стилістичні функції, фоностилістика, індивідуальний стиль, звуконаслідування.

Кабыш М. Ю. Стилистические функции звукописи в поэтической речи украинских поэтов начала XX в.

В статье определены, рассмотрены и проанализированы стилистические функции звукописи в индивидуальном стиле выдающихся поэтов начала XX в. На основе иллюстративного материала показана роль звукоподражания, как одного из приемов звукописи.

Ключевые слова: звукопись, стилистические функции, фоностилистика, индивидуальный стиль, звукоподражание.

Kabysh M. Y. Stylistic features zvukopysu poetic speech in Ukrainian poets of the early twentieth century.

The article defines reviewed and analyzed stylistic features zvukopysu in the individual style of famous poets of the early twentieth century. Based on the illustrations show the role of onomatopoeia, as one of the methods zvukopysu.

Key words: zvukopys, stylistic features, fonostylistyka, individual style, onomatopoeia.

Значення фоностилістики як науки, що «вивчає засоби звукової організації мовлення та виділяє найдоцільніші способи використання природних і функціональних ознак звуків для певного типу мовлення» 6, с. 31], для дослідження української поетичної мови важко переоцінити, адже першоосновою мови прийнято вважати усну форму, iї звукову матерію.

Становлення фоностилістики відбувалося як на основі визначення фонетичних стилів і їх функцій (М. Трубецькой, Р. Якобсон, С. Гайдучик), так і на основі збирання емпіричних (Ю. Лотман, В. Левицький, С. Воронін) даних. Щоправда міркування про функції та форми звукового боку повідомлення у стилістиці донедавна не були обгрунтовані даними експериментального аналізу.

Огляд робіт, присвячених співвідношенню звукового оформлення й семантики висловлювання, переконливо засвідчує, що кодифікуюча техніка мови значною мірою зумовлена глибинною семантичною структурою, яку вона відображає, і тими процесами, що виникають при переході від цієї структури до іï матеріального втілення. Це означає, що ефективне вивчення взаємодії системи фонетичних засобів актуалізації смислу поетичного тексту у відриві від семантичного аспекту мови практично неможливе.

Дослідження останніх десятиліть значно розширили уявлення щодо принципів і форм звукової організації тексту, однак стилістичні функції звукопису до сьогодні залишаються не до кінця вивченими. У зв'язку з 
цим визначення стилістичних функцій звукопису в поетичному мовленні українських поетів початку XX ст. є надзвичайно актуальним.

Метою статті $\epsilon$ визначення стилістичних функцій звукопису в індивідуальному стилі видатних поетів початку ХХ ст.

Новий світогляд початку ХХ ст. породжує нову свідомість, новий тип мислення, інше бачення світу. У художній літературі був зроблений крок до того, щоб зафіксувати складність і рухомість внутрішнього світу людини, що втілилося в поглибленому психологізмі. Формами осягнення дійсності стала поезія, музика - музика в поезіі. Найвиразніше це виявилось у прихильності до звукосимволізму. Представники поетичної творчості початку ХХ ст. загалом прагнуть «музично» передавати душевні стани й емоційні віяння, відтінки й обертони. Власне, розвиваються музичні ресурси української мови, мелодійність. Це спричиняє мобілізацію звукових чи фонетичних засобів стилістики - від ритмомелодики до асонансів, алітерацій, рим, звуконаслідувань, звукопису, що надавало їх творам прозорості, створювалися за допомогою мислезвуків бажані звукообрази, що вносить у поетичний текст надвербальний зміст, сугестивність як здатність передавати напівусвідомлені настрої, відтінки вражень. Яскравий струмінь музичності породжують не тільки фоностильові фігури, чи звукова модель, а й модель асоціативна. Г.-Г. Гадамер вважає, що в мелодищз поезї виражається мелодика мови «це постійно обігрувана рівновага звучання й сенсу, що породжує поетичну форму» [3, с. 119-127].

Художнє призначення звукопису може полягати у звичайному створенні гармонії опису, музичного звучання мовлення, як-от у Г. Чупринки: «Тихо, тихо плеще річка, /Шепчуть казку комиші...». Таке використання звукопису, якщо воно не суперечить логіці тексту, естетично виправдане. Струнке повторення співзвуччя й окремих приголосних надає поетичному мовленню особливої краси: В бурі, в громі (p - p), В льодоломі ....(л -л) Крига кригу (p - p) Серед бігу Ламле, кришить в (л - л- р) Купи снігу, В гори льоду (р - л) (Г. Чупринка „Льодолом”).

Однак, як бачимо, майстри слова зазвичай не задовольняються красою звучання і намагаються застосовувати звукопис, аби вирішити більш складні стилістичні завдання.

Основними стилістичними функціями звукопису вважаємо виражсально-зображсальну, емоційно-експресивну, звуконаслідувальну, смислову, композицийну.

Різноманітні прийоми посилення звукової виразності можуть бути використані задля звуконаслідування: По дорозі торохтить По дорозі порожняк Стук! Гряк! (Г. Чупринка «Порожняк»).

Звуконаслідування в поетичному творі досягається двома шляхами:

1) уживанням ономатопей, тобто слів, які мають звуконаслідувальний характер, імітують певне звучання: крик звіра, птаха, 
звуки робочого процесу, музичних інструментів, а також стихій - свист вітру, гуркіт грому, стукіт, рев водоспаду;

2) творенням потрібних авторові звукових ефектів - наприклад, шум лісу, стукіт мечів - шляхом накопичення певних слів, які безпосередньо не є ономатопами.

Перший випадок можемо проілюструвати уривком 3 поезії неокласика П. Филиповича: I навіть квітка не дзвенить: дінь-дінь, Коли бджола крилом ї̈ торкає...

Проте значно частіше функцію звуконаслідування застосовують, добираючи слова 3 певним звучанням, які створюють враження ономатопеїстичності цілого уривку поезії, однак самі не є ономатопеями. Початок XX ст. ознаменувався низкою невибагливих поетичних продуктів для «робітничо-селянського класу», до них зокрема зараховуємо деякі твори М. Скуби, де звуконаслідування - оголене, подане на поверхні: Г'ex, і рушила ж машина, Не машина, а душа: Тільки иини, як пружини, А під шинами - сома!

Основні причини розбіжностей у поглядах вчених полягають насамперед у тому, що вони підходять до оцінки статусу категорії звуконаслідувальних слів 3 різних науково-теоретичних позицій. У сукупності висловлених 3 цього питання поглядів I. Гаценко виділяє чотири проблемні групи, де розглядаються звуконаслідувальні слова як такі, що: 1) входять до складу вигуків; 2) виділяються в окрему категорію слів у складі вигуків; 3) відносяться до дієслівно-вигукових форм; 4) виділяються до окремої категорії слів [4]. Аналіз фонетичної будови звуконаслідувальних слів дозволив згаданій дослідниці визначити особливості їх структури: ауслаутними приголосними українських звуконаслідувань можуть виступати фонеми: [к], [п], [т], [т’], [Ц’], [в], [м], $[\mathrm{H}],\left[\mathrm{H}^{\prime}\right],[\mathrm{x}],[\mathrm{c}],\left[\mathrm{c}^{\prime}\right],[ц],[\mathrm{p}],[б],\left[3^{`}\right],[3]$, [л] [л']; в анлаутній позиції вживаються такі фонеми: [б], [т], [т`], [п], [г], [д], [х], [ч], [ш], [c], [к], [а],

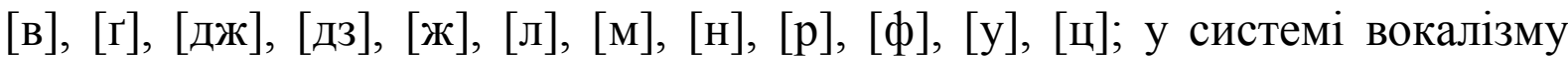
найвища частотність уживання й найпоширеніша сполучуваність зафіксована для вокалічних компонентів /у/ (32\%) та /a/ (24\%).

Поети намагаються передати, застосовуючи звуконаслідування, найрізноманітніші слухові враження. I хоч звуки людської мови не можуть цілковито відповідати реальному «голосові» природи, мова виробила власні прийоми для відображення цих слухових вражень. С чимало слів, які власним звучанням нагадують дії, що номінують (щурхотіти, шепотіти, цзвірінькати, бренькати). Такі слова кваліфікують як ономатопи. Л. Мацько вважає, що «виразною стилістичною особливістю звуконаслідувальних слів $\epsilon$ їх звукозаписний характер» [7, с. 35-39, 37]. Адже за допомогою звуконаслідувальних слів можна не лише відтворити момент звучання, а й змалювати цілу звукову картину, передати звучання в просторі, відобразити його мелодійність або ритмічність, повторюваність 
тощо: «Повне застиглих пісень / Мовчить піаніно. - Дзень...дзень... північна година» (М. Рильський).

Значення ономатопів у поетичному мовленні підсилюється їх фонетичним оточенням: зазвичай звукову виразність слова підкреслюють сусідні алітерації та асонанси, фонічна антитеза, як, наприклад, у поезії О. Олеся: Косять коси, Луг голосе, Косять, косять косарі, А в душі моїи співають, Срібло струн перебирають, Грають, грають кобзарі.

Маємо з одного боку - посвист селянської коси як конкретної реальності, а з іншого - мрію ліричного героя, захоплення романтикою минулого. У подібних випадках звукопис будується на сполученнях ономатопів з фонетично подібними йому словами. Так, у приказці «Bid mупоту копит пил полем летить» головне звуконаслідувальне слово «тупіт», а його фонетична виразність підсилюється алітераціями на /т/, /п/.

В. П. Ковальов наголошує, що «сутність звуконаслідувань полягає саме у звучаннях, які $є$ в такому вживанні і формою, і змістом «слів», - i таких, які створюються в кожному конкретному випадку, i таких, які використовуються в мовленні традиційно» [5, с. 25]. Уведені в текст поетичного твору звуконаслідування посилюють його реалістичність, даючи змогу читачеві не тільки уявити, але й ніби почути те, що змальовує автор. У М. Рильського у вірші «Звуки флейти чути на лужку...» звуконаслідування є складовою частиною рефрену, який то відтворює звуки флейти, то душевні переживання ліричного героя: Звуки флейти чути на лужку: Tiy, тіу, люлю, Місток повис через ріку, Вклоняючись гіллю. I по містку іде дівча - I я його люблю. Воно ж мене ніяк... Хоча Tiy, тіу, люлю, Такий вузький отой місток, Далеко так земля... Озвався на лужку смичок: Тілі, тілі, ляля!

Таким чином, найбільший стилістичний ефект звуконаслідування дає у тому випадку, якщо звукове наближення слів підкреслює їх образність, підкріплює зміст тексту. Коли звуконаслідування народжується 3 самої теми, воно сприймається як природне і необхідне для вираження думки.

Виражально-зображальна функція звукопису пов'язана 3 тим, що символіка звуку може бути цілком прозорою і віддаленою (підтекстовою). Адже звукопис не обмежується змалюванням лише слухових вражень. Діапазон його виражальних можливостей значно ширший: він може відображати різноманітні за характером дії (енергійні, уривчасті, спокійні), відтворювати настрій і почуття ліричного героя: Як смутно... Сухий очерет шелестить...(...) Дзвінке шелестіння бентежно біжить Та, все заміраючи, тихне... Шелеснуло... мение... неначе все диха... Знов тихо, мов руху ніде не було, Мов щуиреє слово, щуо вирвалось тихо I каменем знову на серие лягло, Ніким не почуте... Мов десь загуло... (Надія Кибальчич «Шелестіння очерету»).

У поезії тісно переплітаються слухові та зорові образи осені 3 настроєм смутку. Уривчасті фрази, фонетична організація мовлення 
посилюють виразність слів, що змальовують переживання ліричної героїні. Органічний зв'язок звукопису зі змістом, єдність слова й образу надають мовленню яскравої експресії. Слід відзначити, що звукопис спирається як на повторення окремих звуків, так і на повторення однакових звукосполук: Самотній, з журавлем колодязь Над полем журиться давно. Вмочає сонце в сонну потязь Золототкане полотно (М. Драй-Хмара «М. Хвильовому»).

Під час зорового прочитання можна і не звернути уваги на звукові повтори, але під час прочитання вголос відчувається, що певні звукосполуки повторюються. У наведеному уривку на ненаголошену звукосполуку жур першого рядка відгукується наголошена звукосполука жур другого, а в четвертому рядку з першим перегукується українське повноголосне оло.

Зображальну функцію може виконувати не лише звучання слів, але й рух артикуляційних органів - подібне інструментування називають кінетичним. У поєднанні 3 іншими стилістичними прийомами інструментування поетичного тексту на приголосні, у творенні яких беруть участь зуби, отримує символічне значення: у самій артикуляції звуків угадується печаль та радість (посмішка): Ситом сіє сиві струї Хтось химерний. Хмар хитон Розпростер на небі вітер. Слизько. Слізно. Сумно. Сон. Вимок ворон на воротах. Сльози скапують зі стріх. Ластівка пройшла, як стрілка. Сниться: Сяйво. Сонце. Сміх (Роман Купчинський «Слота»).

У поетичному мовленні виражально-зображальні функції виконують різноманітні, навіть «неестетичні» звуки і звукосполуки.

Емоційно-експреситвна функція звукопису полягає у смисловому виділенні відрізків поетичного мовлення, у наданні автором окремим відрізкам висловлення більшої чи меншої міри важливості. Експресивність за О. Селівановою, - це «ознака інтенсифікації значення слів за шкалою зменшення та збільшення різних денотативних i конотативних ознак, зокрема логічного змісту, оцінок й емотивності. Експресивність переважно пов'язується 3 різними видами оцінок й емоціями суб'єкта мовлення, виступає засобом увиразнення тексту й виявляється на різних рівнях мови, зокрема i фонетичному як не релевантні для мови зміни звуків, тип вимови, просодичні засоби, звукопис тощо» [8, с. 139-140]. Неповторний світ інтелекту, почуттів та емоцій, волі людини є невидимим для інших. Однак звукопис поетичної мови надає найбільше можливостей розкрити внутрішній світ автора для інших людей, вплинути силою своїх переконань чи почуттів на читача: Тебе любить, усе забуть! Ти зрозуміла? Єднає нас єдина путь, Єдина сила (М. Рильський).

Цікаву концепцію поетичної мови можна знайти в працях М. Бахтіна, який стверджував, що лише в поезії мова розкриває всі свої можливості, оскільки тут для неї існують максимальні вимоги: «... поезія немов віджимає всі соки з мови, і мова перевищує тут саму себе» [2, с. 32-44]. Емоційна сила поетичного мистецтва виникає не спонтанно. Це результат глибокої думки і почуття. Створюючи свій твір, поет враховує, як усе показане й 
описане ним буде впливати на людей: Сонце заходить, лідо леліє, У сріблі луни лагуна мріє, А гондоліре, кращчий Аполла, Пустився барков долів на море... (Ю. Федькович).

Художню форму поданого уривка поетичного твору характеризують емоційно-експресивна виразність, пластичність вислову, невимушеність вірша, довершеність звукопису (алітерація на “л” i “p”). Як бачимо, українські поети уміють, за словами В. Базилевського, «смакувати звуком» [1, с. 195], уміють вони також і грати звуком, як-от: Серденьку легко-легко, Бо прогнали сум далеко Дзеньки-бреньки. Ллються, в'ються I сміються Дзеньки-бреньки, Різнотонні, Різнодзвонні, Солоденькі, Золотенькі Життьові брехеньки... («Дзеньки-бреньки (поетичний жарт)» Г. Чупринка).

Звукопис також виконує важливу смислову функцію в поетичному мовленні: підкреслювати важливі з логічного погляду слова, художні образи, мотиви, теми. Фонетична подібність допомагає поетові створювати і читачеві відшукати смислові зв'язки між словами - таким чином фонетика породжує думку. Саме звукопис допомагає зрозуміти глибинний смисл поезії «Серпневий прохолонув вар» М. Драй-Хмари. Її зміст - ніби опис серпневого вечора, але кінцівка: Вдягає ніч жалобне рам'я. О, хто це ранить утлу пам'ять? День одгорів. Давно - раптом переводить читача у внутрішній світ поета, переживання якого пов'язані з революційними подіями, які не дають спокою його пам'яті. Звукопис посилює логічні аспекти мовлення: фонетично виділені слова набувають у тексті особливої ваги, підкреслюючи змістову близькість, однорідність предметів чи явищ, підкріплюючи граматичні зв'язки слів у тексті: Сонце зникало хмаряно На фіолетовому бруку I журилось марно І ждало грюку Після дощу («Місто» Михайль Семенко).

Звукопис також може відігравати композиційну роль: надавати схожого звучання смисловим відрізкам поетичного мовлення і відмежовувати або протиставляти фонетично кожен новий поетичний образ: Як дуже обридне сумне нарікання Моїх обезсилених темних братів, I праця селян, $і$ довічне страждання, I торг невсипущих гучних городів. То тиша й самотність зеленого гаю Милімі мені од шумливого краю («В гаю» Г. Чупринка).

У поданому уривку образ гамірливого міста 3 великою кількістю знедолених мешканців протиставляється образу спокійного затишного гаю, дисгармонії урбанізації протистоїть у звукописі гармонія природи. Таким чином, розвиток теми послідовно відображений в алітераціях і асонансах (так, початковий повтор звука /p/ змінюється переважанням звуків /ш/, /с/).

Як бачимо, на основі одних із найяскравіших зразків поетичного мовлення українських поетів початку XX ст. можна легко проілюструвати стилістичні функції звукопису, визначити їх особливості, роль у сприйнятті поезій читачем.

Складність і самодостатність, тонке світовідчуття, наскрізна інтелектуальність української поезії початку ХХ ст. виявляється в умінні 
митців віднайти глибоко заховані культурні нашарування асоціативних зв’язків, завдяки яким розкривається, міниться барвами, перешіптується чи гуркотить, суне чи лине, бринить, пульсує крізь звукообрази, словообрази, тропи довершена гармонія української мови.

\section{Література}

1. Базилевський В. О. Логіка поезії / В. О. Базилевський // Базилевський В. О. І зав’язь дум, і вільний лет пера : [літ. - критич. статті, есе, студія одного вірша]. - К. : Рад. письменник, 1990. - 318 с.

2. Бахтин М. М. К эстетике слова / М. М. Бахтин // Контекст. - М. : Наука, 1973. - С. 32-44.

3. Гадамер Г.-Г. Філософія і поезія (1977) // Гадамер Ганс-Георг. Герменевтика і поетика : Вибрані твори. Переклад з німецької. - К. : Юніверс, 2001. - С.119-127.

4. Гаценко І. О. Типологічні особливості звуконаслідувальних слів (на матеріалі української, російської та англійської мов) : автореф. дис... канд. філол. наук: 10.02.15 / І. О. Гаценко. - НАН України. Ін-т мовознав. ім. О. О. Потебні. - К., 2003. - 19 с.

5. Ковальов В. П. Виражальні засоби українського художнього мовлення / В. П. Ковальов. Херсон : ХМВ, 1998. - 125 с.

6. Мацько Л. І. Стилістика української мови : [підручник] / Л. І. Мацько, О. М. Сидоренко, О. М. Мацько. - К. : Вища школа, 2003. - 426 с.

7. Мацько Л. І. Стилістичні функції звуконаслідувальних слів / Л. І.Мацько // Культура слова : Республ. міжвід. збірник. - Вип. 22. - С. 35-39.

8. Селіванова О. Сучасна лінгвістика : термінологічна енциклопедія / О. Селіванова. - Полтава : Довкілля-К, 2006. - 716 с.

Стаття надійшла до редакції 29.11.2011 p. 